\title{
Management of Third Sector Highland Development Projects in the Upper Northern Region of Thailand
}

\author{
Jumpol Chaiwong \\ (Email Address: jchaiwong97@gmail.com)
}

\begin{abstract}
In this dissertation, the researcher investigates (1) the management process involved in Third Sector highland development projects in the upper northern region of Thailand; (2) conducts a strategic management analysis of these projects; (3) inquiries into the results of the management of these projects, and; (4) provides new information concerning the management of the projects under study.In this study, the researcher focused on six organizations: (1) Mae Fah Luang Foundation under Royal Patronage; (2) Highland Research and Development Institute (Public Organization); (3) Population and Community Development Association; (4) Raksthai Foundation; (5) Plan International Thailand Organization, and; (6) Heifer International Thailand.
\end{abstract}

Keywords: project Management , the Third Sector, the Upper Northern Region of Thailand

\section{Introduction}

Highland development in the upper northern region of Thailand is conducted not only by the public and private sectors, but also by another type of organization called "the Third Sector". Third Sector organizations are nowadays playing an important role in community development in the upper northern region of Thailand. Inasmuch as there have been no previous Public Administration academic studies of these Third Sector projects, the researcher was interested in providing new information and data concerning this new area of inquiry.

In carrying out this investigation, the researcher utilized a conceptual framework that was applicable to the following three issues:
The first issue involved the process of project management in seven dimensions: (1) organization structure; (2) planning; (3) personnel management and development; (4) budget; (5) leadership; (6) control and evaluation, and; (7) organization ethics.

The second issue required focusing on strategic management in three dimensions: (1) vision; (2) mission, and; (3) strategies.

\section{The third issue necessitates examining the results of project management in four dimensions:}

(1) the economy; (2) society; (3) the environment, and; (4) attitudes toward the general public.

Accordingly, the researcher collected data from: (1) primary sources taken from field study work in conducting in-depth interviews with administrators, personnel, community leaders, and local people participating in the projects, group discussions, and participatory and non-participatory observations, and; (2) secondary source materials involving documents, articles and related research inquiries.

\subsection{Findings are as follows:}

The six Third Sector organizations conducted project management largely in accordance with a matrix organizational structure. The management stressed delegating authority and community participation in improving projects at all project stages involving planning, operations, using the budget, and follow-ups and evaluations of projects. Authority was decentralized, inasmuch as high-ranking administrators delegated decision making to lower-level managers and encouraged teamwork at lower levels in a process of project decentralization. Project administrators embraced a form of democratic leadership by 
stressing collective decision making and work processes, good ethical practices, teamwork, paying mutual respect and placing value on all involved to ensure the successful execution of projects. Most applied the concept of sufficiency economy to project management.

In addition, it was also found that Third Sector project management made use of a strategy of network cooperation with community organizations and private sector organizations at the local level.

Findings concerning project management in the four dimensions considered by the researcher are as follows:

(1) In respect to the economic aspect, it was found that Third Sector management developed a strategy of promoting sustainable agricultural production.

(2) In this connection, autonomous groups were organized in such a fashion that they would be able to overcome the problem of poverty by fostering income generating occupations and to solve the problem of internal and external social conflict so that communities could develop effective social networks.

(3) In regard to the environment aspect, group support for conserving and sustaining the environment was fostered by allocating a budget for this purpose.

(4) As for the aspect of attitudes toward the general public, the researcher found that community leaders and most of the local people involved in the projects were aware of the benefits to be received and were willing to exchange the role of "receiver" to that of "giver."

\subsection{Suggestions in regard to policy on the basis of this study are as follows:}

Most of the local people do not have Thai citizenship. Therefore, the researcher suggests that the government adopt a policy of examining the question of citizenship for highland residents in conjunction with the amassing of appropriate data by sub-district administration organizations, community organizations and NGOs involved in highland development.
Guidelines could then be formulated for systematically dealing with the serious problem of highlanders not having Thai citizenship. Since the Third Sector organizations have limited budgets, it is suggested that the state should establish an independent organization to provide financial, academic, technical and informational support.

\subsection{Background}

The upper northern region of Thailand consists of hills and forests, and is a residential area for more than 10 tribes and ethnic minorities. The hill tribes are mostly Karen, Hmong, Lahu and Akha. These areas are considered very important upstream sources of water for the country. During the past 40 years, the population growth rate of hill tribes has rapidly increased, and accounted for $80 \%$ of the total population scattered sparsely along the hills. They needed more area for cultivating opium to earn a living, but due to their increasingly rapid population growth, various problems arose that can be summarized by the following issues:

Intrusion deforestation: Although the problem of opium cultivation is now only slight, intrusion deforestation still exists. In addition, the legal use of land by the government promoting single crop agriculture, constructing roads, and building reservoirs and dams seemed to increase problem of intrusion deforestation. Moreover, the growth of resort golf courses, parks, and other agricultural encroachment enhanced this serious problem because of the use of machine tools in the invasion, destroying and opening forest areas which lead to more natural disasters such as floods, landslides, forest fires, and soil-erosion. (The Office for Academic Services, Chiang Mai University, 2008, pp.1-1).

The problem of natural resource degradation: The land is no longer suitable for agriculture. This was a result of the traditional slash-andburn agriculture of hill tribes in which the cultivated area is constantly moving location depending on the fertility of the land. This kind of agriculture called "shifting agriculture" which exposes the surface of the soil to rain and results in direct erosion resulting in a reduction of soil fertility, and with cultivated land becoming rocky.

The problem of agricultural chemicals residues in soil and water: Inappropriate agricultural production by farmers who live on 
the uplands is due to a lack of appropriate knowledge and skill in production. This problem affects water resources and people who live in and around downstream areas (The Highland Research and Development Institute (Public Organization), 2007, pp. 32).

Poverty: In general, most of the people living in the uplands are poor. According to baseline survey data from 2004 conducted by Chiang Mai University, the average annual income of households was only around 1,004 US\$. The crucial factor of poverty was due to low yields in agricultural production but high costs, as the price of agricultural produce is relatively low and fluctuates, as well as having limited marketing channels. In addition, farmers lacked opportunities to generate additional income from non-farm activities which led to insufficient income to offset household expenses and there was a wide difference of income distribution in their society. (Highland Research and Development Institute,(Public Organization), 2007, pp. 32).

Conflict of Interest in Utilizing Natural Resources: This was conflict between people who benefited from natural resources, particularly the conflict between people who live in and around upstream areas and people who live downstream, leading to conflict between the state and local community. These conflicts were caused by differential exploitation resulting in a usurpation of resources in the uplands. (Highland Research and Development Institute, (Public Organization), 2007,pp. 32).

Social Problems: The highlands in upper region of Thailand are not only sparsely settled but have different cultures, ways of life, beliefs and religions among hill tribes, and the way of life of hill tribes also differs from people living in the lowlands. In this regard, it has led people in the uplands exposed to risk of various social problems such as youth problems, lack of social awareness, drugs and HIV/AIDS, and security problems along the border of the country.( International Academic Institute, Chiang Mai University, 2004,pp. 54-55).

The problems mentioned above have been occurring for a long time in spite of the government and private sectors' ongoing cooperation and participation in solving problems. Nevertheless, there have been obstacles in that work never run smoothly according to planned targets. Such obstacles are as follows:
Difficulty in accessibility of the locations of communities on the uplands. The obstacle of accessibility impacts development of basic services of the state including a better marketing system. This directly results in low efficiency of production, which in turn brings about the problem of poverty, food security, illiteracy, and higher rate of illness as well as drug use. This is also due to settlements of highland people being mostly near to the borders of neighboring countries, so it is difficult to control drug trafficking.

Attitude. People who live in the plains areas and government agencies misunderstood communities in the highlands, especially communities in the upper northern region of Thailand located near the origins of four main rivers - the Ping, Wang, Yom, and Nan which join to become the Chao Phraya River. Deforestation of the upstream areas of these rivers lead to the problem of soil erosion and making the river shallow, while soil erosion can occur downstream as well. In addition, destroying the natural environment of the highlands causes both severe flooding and severe drought as well. Meanwhile, people who live in the lowlands believe that they are at risk from agricultural chemical residues coming from the highlands. ( Office of Academic Services, Chiang Mai University,2008, pp. 2-8)

Diversity of Culture and Society. This remains a crucial obstacle to work between the community and government sector. Hill tribe communities in particular often suffer mutual misunderstanding. Previously, it was hard to manage various problems in the society on the highlands. (Office of Academic Services, Chiang Mai University,2008, pp. 2-8).

The above problems in local communities are national problems that every sector has to participate in solving in order to rehabilitate the ecological balance of soil, water, air, and the quality of life of people who live with nature. The government sector is directly responsible for executing various development activities for a better quality of life of the people on the highlands by stopping opium cultivation and promoting sustainable agriculture coupled with conservation of natural resources and other environmental factors for people. However, the government sector still lacks personnel who are knowledgeable and amenable towards development of the highlands, including lack 
of an appropriate budget. These have led to the failure of government projects, and other government sector projects not yet succeeding in their goals. The business sector, which is objectively established as profit-making organizations, and large organizations are capable in both budget and skilled staff in production, marketing, production, and services, and have begun to pay more attention to, participate in, and be responsible for social and environmental problems respectively. However, the business sector has lacked personnel who are really aware of and understand local social problems and who are ready to contribute to development activities which are social beneficial to society as a whole. For these reasons, another type of organization called "the Third Sector Organization" has come to play a remarkable role in cooperating to help close the gap between obstacles of the government and business sectors by alternative co-development of the upper northern region of Thailand.

\section{The importance of Third Sector Organization}

The third sector refers to non-governmental organizations (NGOs) or voluntary organizations (VOs) which are considered nonprofit prganizations (NPOs). Most were established by individuals or by groups with the intention of helping to alleviate social problems and to meet the needs of this diverse and complex society. The third sector has a vital role in public administration in almost every country, be they liberal economic or socialist countries, or developed and developing countries. For funding, the third sector is funded by several sources or donors such as individuals, groups, and organizations, especially the government and semigovernment sector, business sector and other third sector organizations themselves. The third sector organizations work to achieve their objectives which focus on solving social problems or to meet social needs in order to gain trust, satisfaction and respect from the public or, especially, communities which are the targeted group of the organization, so as to be accepted by donors who support funding if the project objectives are carried out by the management. In other words, the third sector is not only working to meet social needs, but they also work to meet needs of donors as well
(David C. Korten, 1987, pp. 148). In order to fulfill the expectations of society, the third sector organizations necessary seek capable personnel, appropriate technology, tools, and good management if they need to accomplish the overall goal of the organization which means organizational growth and organizational survival. To achieve its goal of organization, mobilization of resources from external sources is prerequisite. Fund raising in particular seeks large sums of capital that are often in the form of funds for development projects with conditions written in accordance with rules and regulations and conditions for consideration by donors. This means that every project is in competition, so some do not succeed in receiving funding from governmental, semi-governmental, and the corporate sector, as well as third sector organizations working as donors to other NGOs. Usually, funding sources are available both domestically and from abroad. Operation of third sector organizations is in the form of "projects", therefore, the "goods and services" of the third sector organizations is "projects". By all means, this is quite similar to the goals and missions of the governmental and business sectors. So integration of thought and values as well as principles of both the government and business sectors apply to the third sector: nongovernmental development organizations (NGOs) or non-profit organizations (NPOs) are classified and grouped by scholars in the field of organizational studies as "The Third Sector". In this dissertation, the researcher investigates: (1) the management process involved in Third Sector highland development projects in the upper northern region of Thailand; (2) a strategic management analysis of these projects; (3) inquiries into the results of the management of these projects, and ; (4) provides new information concerning the management of the projects under study.

In this study, the researcher focused on six organizations: (1) Mae Fah Luang Foundation under Royal Patronage; (2) Highland Research and Development Institute (Public Organization); (3) Population and Community Development Association; (4) Raksthai Foundation; (5) Plan International Thailand Organization, and; (6) Heifer International Thailand.

\section{Concepts and theories formulating a conceptual framework}


Concepts and theories that the researcher utilized to formulate a conceptual framework for this research are as follows: scientific management of Frederick W. Taylor and Frank Bunker Gilbert regarding the design of human work, such as the best way to design work to fit human capacity, work standards to generate as much output as the manager and staff can achieve by using division of labor and in- an pre-employment training of staff, and payment incentives by piece in order to control the efficiency of work within the workplace. In addition, the 14 principles of management of Henry Fayol and bureaucracy theory of Max Weber are useful for examining the design structure and internal systems and standards design according to needs of top management, and to ensure all resources of an organization manpower, money, equipment and tools, and information - are effectivelyutilized. Furthermore, theories of organizational structure by Henry Mintzberg and Stephen P. Robbins, decision making theory of Herbert Simon, concepts of organizational project management of Turner \& Bruke, the classification of projects by JL Goodman and N.R. Love, the concept of team building by Coming and Worley, and leadership theories by Ransis Likert, Frederick Herzberg, Bernard Mausner and Barbara Snyderman, Henry Mayo and Paul H. Appleby are necessary to analyze both characteristics of the organizations and the processes of project management. In order to investigate strategic management of the six third sector organizations, the researcher utilized concepts of strategic management written by Thomas L. Wheelen \& David J. Hunger, and Jeffrey S. Harrison \& Caren H. St. John. For examining project management, the researcher adopted large project management written by Philip Selnick, strategic project management of RJ. Turner, and comparison of project cycle management of the public sector and private sector written by Pakorn Preeyakorn. For investigation of the results of project management, the researcher utilized the concept of sustainable development identified by the United Nations, concepts of environmental conservation collected by Somporn Sangchai, concepts of development written by Irwing Swerdlow, the principles of sufficiency economy written by Abhichai Phandhasen \& colleagues, sustainable agriculture development conceptualized by the Sirindhorn Anthropology Center (Public
Organization), the strong community approach generated by the Community Development Department, Ministry of the Interior, Thailand, networking concepts written by Suthita Aphakalo Bhikkhu, and local cultural based development concepts written by Kanchana Kaew-thep and Chatthip Nartsupha.

\subsection{In carrying out this investigation, the researcher utilized a conceptual framework that was applicable to the following three issues:}

The first issue involved the process of project management in seven dimensions: (1) organization structure; (2) planning; (3) personnel management and development; (4) budget; (5) leadership; (6) control and evaluation, and; (7) organization ethics.

The second issue required focusing on strategic management in three dimensions: (1) vision; (2) mission, and; (3) strategies.

The third issue necessitates examining the results of project management in four dimensions: (1) the economy; (2) society; (3) the environment, and; (4) attitudes toward the general public.

Accordingly, the researcher collected data from: (1) primary sources taken from field study work in conducting in-depth interviews with administrators, personnel, community leaders, and local people participating in the projects, group discussions, and participatory and nonparticipatory observations, and; (2) secondary source materials involving documents, articles and related research inquiries.

\subsection{Findings are as follows:}

The six third sector organizations conducted project management largely in accordance with a matrix organizational structure. Namely, there were four organizations that designed the structure of organization as a "matrix organization" whereas the other two organizations used "pure project organization". By using pro and con analysis as a tool in explanation of the first-four matrix organizations, the structure of the matrix organization could help support strategies of top management to optimize work performance of all personnel working on both routine work and projects. In addition, the matrix structure of organization could also help save costs of investment in managing and developing human resources of the organization in the long run. However, it also created some cons: the first 
being that it caused an overlap of power and authority between managers along the chain of command of routine work and the project manager. The second one was an insufficient number of personnel in some positions in routine work selected to work in remote areas of the mountains usually targeted as the project working areas. In the other two organizations which designed the structure of organization as "pure-project organization", the project structure is well-designed in consistence with the small size of the two third sector organizations and the management of the two organizations were merely based on projects. When the management process is examined, management stressed delegating authority and community participation in improving projects at all stages including planning, operations, budget, and follow-up and evaluation of projects. Authority was decentralized, inasmuch as high-ranking administrators delegated decision making to lower-level managers and encouraged teamwork at lower levels in a process of project decentralization. Project administrators embraced a form of democratic leadership by stressing collective decision making and work processes, good ethical practices, teamwork, paying mutual respect and placing value on all involved to ensure the successful execution of projects. Most applied the concept of sufficiency economy to project management.

In addition, it was found that third sector project management made use of a strategy of network cooperation with governmental agencies, community organizations and other NGOs and business sector organizations at the local level. The strategy of a networking cooperation system was not only adopted for organization at the local level, but it was also adapted to promote various groups established under project management from the six organizations, such as a network of savingsbased credit groups (micro finance groups), marketing network of agricultural production, a network of youth groups for natural environmental conservation, a network of watershed management committees and a network for forest-fire protection.

\subsection{Findings concerning project management in the four dimensions considered by the researcher are as follows:}

In respect to the economic aspect, it was found that most inhabitants of the highlands were stateless and legally landless farmers living in areas of forest preservation as determined by the Department of Royal Forestry. In addition, farmers were faced with limitations on cultivated land and a lack of proper knowledge about the use of chemical inputs in agricultural production which put them in danger from the side-effects of chemical, as well as personal hygiene risks by using chemicals in vegetable production and on other crops. Moreover, they were not safe from eating agricultural products contaminated with chemicals as well. In other words, conventional agricultural production on the highlands effected both those who live on the highlands and those who live in the lowlands in negative ways for the quality of life of the public as a whole. For economic problems, project management mostly had developed a strategy of promoting sustainable agricultural production for income security generating activities for farmers in the form of self help groups which were established and developed by the projects. The strategies for strengthening of income generating activities via self help groups can be divided into three steps: First, the project set up the self help group in each community with members of the group from each household and the group committee came from a selection of members, consisting of both males and females. Second, providing group members with a study tour on group management and sustainable agricultural occupations from the successful self help groups. After that, the projects provided several vocational training courses on various subjects concerning hygienic vegetable production and cropping plantation. The projects also promoted animal husbandry, especially pig raising, because the pig is a prolific animal that is easy to make a profit from. Traditionally, pigs were allowed to roam free and find their own food. However, pig mortality rates were high, and it took 2-3 years for an animal to grow to market size. The supply of pigs for home consumption and for sale was quite limited, so, in order to help provide villagers with more pigs for their own table and for sale to the market, the projects have introduced a multi-faceted program. The projects provided pig producers with training on the proper health care of pigs, including the construction of pig pens or sties which help reduce the incidence of diseases and parasites both in the pigs and in the humans who come into contact with the pigs. These hybrid pigs 
reach market weight more quickly -in only 810 months. The projects also provided villagers with half-breeds which are a mixture of traditional breeds and imported breed pigs from Yunnan, China. This breed is called "Meishan" and even breeds called "Duroc Jersey" are taken from pig farms on the lowlands. This increases the amount of protein in the villager's diet as well as increasing their cash income from the sale of pigs. Raising pigs also helps farmers reduce the risk of disaster should one or more of their crops fail. In addition, to help farmers reduce the cost of feeding the pigs, some projects requested assistance from experts of the department of livestock promotion in teaching farmers how to prepare their own pig feed using locally grown corn rather than purchasing expensive readymixed feed from urban markets. For vegetable producers in the targeted villages of the projects, the projects provided environmentally friendly techniques to produce organic vegetables. The various crops included cut flowers by organizing training courses on how to produce organic vegetables, crops and cut flower plantations without (or with less) use of chemical inputs such as fertilizer, insecticide and pesticide. Third, the projects promoted a savings based credit system (SBCS) to the self help groups as a helping tool for generating income from the regularly accumulated savings funds of its members, and, at the same time, enabling each member not only to learn about saving, but also to benefit from the dividend of shares after paying back the loan from members who borrowed money from the savings fund. However, in order to keep up with the time management of the project effectively, the projects enhanced the management strength of each SHG to be self reliant by adding financial support to the self help groups in two ways, namely; (1) assistance in the form of revolving funds (RVF) or "in-cash assistance". This RVF was one financial tool of The Population \& Community Development Association (PDA) in strengthening individual members of self help groups who lacked capital in agricultural production. After finishing the training, each one could apply for capital from the projects to buy farming inputs and the borrower paid back to the project without interest after selling farming produce so that the project can be used for other members. This system was designed for use only by the management of the PDA. (2)
Assistance in the form of revolving loan funding (RVLF). This system was designed for use in the management of savings-based loaning systems of self reliance promotion of the self help groups in the projects by providing certain amounts of funding from the projects through the management system of each self help group. To start with, RVLF provided loans with lower interest rates than those of local creditors to members of SHGs and finally, the projects hoped that the main sources of income for SHGs would be sufficient from RVLFs and SBLs. With regard to marketing promotion for hygienic agricultural outputs, such as organic vegetables and commercial animals ( cattle, pigs and poultry such as chickens and mandarin duck etc.), there were no problems, because after household consumption, the remainder was sold in the market outside of their communities. Nowadays, hygienic agricultural yields have increased in popularity especially for chemicalfree vegetables (organic vegetables), but not for some crop outputs such as rice, corn, tea and coffee. Some third sector organizations have developed a new alternative by initiating the marketing networking system of self-help groups at a sub-district level, which was initiated for risk management of the projects by promoting value added goods produced from agriculture such as rice grain goods in different attractive packages etc., and the projects have also encouraged SHGs to think outside the square in promoting income generating activities from non-agricultural sources for the community. Examples of this include promoting rural cultural tourism, or eco-tourism by simultaneously promoting handicrafts for additional income for farmers' families. By cooperation with the corporate sector in the tourism business, projects could help generate more income for both the community and villager SHGs. The fourth is the last step before ending the projects as scheduled. The projects stressed strengthening of self help groups so as to ensure the sustainability of community enterprises by enhancing the capacity of SHGs with specific training courses on financial management with appropriate computer -based accounting, adjusted to fit the size of group and capital funds, including competency of members who were accountants and clerks. In addition, some projects developed their capacity to meet the requirements to be registered as legal entities 
such as an agricultural cooperatives organization, and/or a foundation, and some SHGs had developed the organizational capacity to achieve the conditions of the Bank for Agriculture and Agricultural Cooperatives (BAAC) in applying for special loans from the BAAC. Meanwhile, some SHGs preferred to be registered as a "community enterprise organization" (CEO) to meet the financial subsidizing conditions of government agencies. Some SHGs could develop their management capability to work as a "partner organization" of some third sector organizations whose strategy was extending the scope of project areas without recruitment of new staff, but rather utilizing CEOs in the community instead. In conclusion, in respect to the economic aspect, the outcome of project management in the forms of legal entities could function as a "umbrella organizations" in helping, supporting and solving the problems of its members who were the members of small SHGs and of new SHGs which were not yet self reliant.

In connection to topic (1), autonomous groups were organized and promoted in different forms of entity, depending on both the needs of groups and the socio-economic context of each group in order that they would be able to overcome the problem of poverty by fostering income generating occupations and to solve the problem of internal and external social conflict so that communities could develop effective social networks. As mentioned earlier, hill-tribes are mostly stateless, so they are disadvantaged in access to basic assistances by the government. For example, stateless people are not eligible to apply for loans from the Bank for Agriculture and Agricultural Cooperatives (BAAC) and they could not apply for loans from commercial banking systems or even apply for funds from the village development fund (VDF). In addition, stateless people who live on the highlands can not receive social welfare from the state - not even health care services when they were sick and had to go to hospital. Moreover, poverty and lack of opportunities for a better job for stateless girls often led to human trafficking and the girls became prostitutes which caused physical and metal anguish in the young women and their parents. These situations should not occur in any society. So, to solve these problems, it seemed that poverty was the root cause of other problems. Establishment of self-help groups (SHG) was the first priority in the development project management of the third sector organizations. This activity was the key for the projects in mobilizing resources in the communities to solve the problem of poverty on their own in both the short run and the long term. In the short term, SHGs were assisted by the projects in organizing the group in the community; in other words, the projects were firstly mobilizing "social power", followed by mobilizing a "social fund" from members of SHGs through savings activities of SHGs, and thirdly, members and group committee of SHGs were encouraged by the projects to carry out SHGs to become self reliant groups in both economic and social aspects. In addition, the participation of villagers in SHGs in the community could lead them to resolve conflicts in their families. For instance, for social equity beliefs according to the traditional conduct of the Lahu, routine work in the household is regarded as only for female members or housewives, it was not a responsibility of males. But after attending the training courses on "The Role of Males and Females in Managing Self-Help Groups" the role of males in the community changed. Husbands recognized how to be a proper leader of the family by undertaking some duties that had previously belonged to housewives in the routine work in the household. Moreover, this not only allowed housewives to participate in communal activities, but it also led to an acceptance of the "role of women" in the matter of leadership in the group committee of SHGs. Apart from successfully mobilizing resources within communities or societies in the project areas, the projects had guided SHGs in creating a co-vision for how to mobilize external resources, including governments, the corporate sector, NGOs, beneficial groups, and individuals. External resources refers to resources that could be utilized in strengthening the self reliance of groups and communities in the long run, such as money, materials, workforce and know-how, or even the opportunity to prove to one-self whether is worth applying for Thai citizenship. After the projects could develop the quality of life of SHGs and their members in terms of socioeconomic resource mobilization, to a certain extent, it enabled members to know how to be good recipients by utilizing and managing acquired resources effectively in line with the 
concept of sufficiency economy that focuses on living sufficiently with rationality, wisdom, knowledge and morality in earning a living and living in society. The projects had shown that in terms of social development, SHGs learned to work with others through networking systems under networking concepts and could help SHGs and communities learn how to live in interdependence with each other without conflict of interest.

In regard to the environment aspect, group support for conserving and sustaining the environment was fostered by allocating a budget for this purpose through the management of SHGs at a village level and through the networking committee for environmental conservation that was established in the form of a joint committee by working as a network for protecting forest preservation areas and upstream areas that belong to the community where the SHG is located. Apart from allocating a budget from the projects to support environmental activities, i.e. surveillance for forest fires and reforestation activity including construction of small dams (check-dams) and reservoirs for keeping soil moisture and forests for rehabilitating the balance of nature. These activities in fact take a long time and have to be implemented continuously. Thus, all SHGs agreed with the idea of the project to allocate the budget from the profits from income generating activities of the SHG as mentioned in topic (1) every year for this purpose.

As for the aspect of attitudes toward the general public, the researcher found that community leaders and most of the local people involved in the projects were aware of the benefits to be received and were willing to exchange the role of "receiver" to that of "giver." As mentioned earlier, villagers involved in the projects, especially in working with SHGs, had learned how to mobilize resources for developing their self help groups (SHGs). These activities were a very important experience in incubating a good attitude in members of SHGs about working for the public interest through activities, particularly SHGs that had allocated a budget from profits for social development activities, for example, scholarships for poor students, social welfare to members admitted to hospital, and promoting traditional customs and supporting sports in the community, as well as allocating budget to support the environmental development activities that was mentioned previously. These activities encouraged local people to become more public-minded.

\section{Conclusions}

Most of the local people do not have Thai citizenship. Therefore, the researcher suggests that the government adopt a policy of examining the question of citizenship for highland residents in conjunction with the amassing of appropriate data by sub-district administration organizations, community organizations and NGOs involved in highland development.

Guidelines could then be formulated for systematically dealing with the serious problem of highlanders not having Thai citizenship. Since the third sector organizations have limited budgets, it is suggested that the state should establish an independent organization to provide financial, academic, technical and informational support.

\section{Acknowledgements}

This article is part of the author's dissertation which was accomplished with the good care and kindness of Associate Prof. Dr. Somporn Sangchai as the chairman of the advisory committee of the dissertation.

Many thanks to Dr. Suchart Sriyarunna and Dr. Surang Virakitpanich who gave good advice in regard to methodology and content of the dissertation.

Special thanks to Professor. Dr. Voradej Chantharasorn who was the chairman of the examination committee for this dissertation and who kindly gave additional useful advice that enabled this dissertationto be of more value to the field of development administration in the third sector organizations in Thailand.

In addition, I would like to thank Dr. Pakorn Siriprakorb who was one of the examination committee of this dissertation and who helped revise the accuracy of wording in this dissertation that made it more useful and interesting for readers.

Finally, the author would also like to thank the College of Public Administration, Burapha University for providing an opportunity to me as an author to present this article to the public. Jumpol Chaiwong 


\section{References}

[1]Ministry of Interior, Department of Community Development (2005). Community Development 1999. Bangkok.

[2]Kanchana Kaewthep. ( 1995). HumanCentered Cultural Community Development. Bangkok. Catholic Council of Thailand for Development.

[3]Chattip Nathsupha. (2004).Thai Culture and Social Change Process (Fifth Edition) Bangkok.: Chulalongkorn University.

[4]Chaiyut Chinokul (2 003). Strategic Management : Strategy Implementation. Bangkok: Sukhum and Son.

[5]Chaiyanan Samuthavanij and Kusuma Sanitwong $\mathrm{Na}$ Ayuthaya. (2 003). Environment and Security: Security of Government and Un-security of People (Second Edition). Bangkok: Sukhum and Son.

[6]Chairat Charoensin-o-larn. (2002). Development Discourse (Third Edition). bangkok: Viphasa Print.

[7]Benjamas Siriphat and Surapol Mulada. (2002). "NGO" The Developer At Grassroot Level: un-lacking-Human Race for society ?. : Community Institute for Local Development, Office for Community Health Promotion.

[8]Pakorn Preeyakorn. ( 1999). Project Management: Concept and Guidelines for Success (Seventh Edition). Bangkok: Semadhama Print.

[9]Praves Wasi. (1999). Sufficiency Economy and Civil Society Concept : Concept for Economic and Social Recovery. Bangkok: Mor Chao Bann Foundation.

[10]Preecha Peampongsan. (2 005). Environment and Development. Bangkok: Chulalongkorn University Printing.

[11]Phromboon Phanichaphak. (2007). Development in Development. Bangkok: Amarintha Printing and Publishing.

[12]Bhra Maha Suthith Arphakaro (aom-oon). (2004). Network: Nature Knowledge and Management Bangkok: October Printing.

[13]Mayuree Anumanratchadhon. (2 001). Non-Profit Organization Management: Principles and Practices. Bangkok: Thanut Printing.
[14]Mayuree Anumanratchadhon. (2 008). Project Management. Bangkok: Chulalongkorn University Printing.

[15]Chiang Mai University, Institute for Academic Services. (2 004). Strategy for Highland Agriculture Development in 12 Province, Northern Region of Thailand.

[16]Chiang Mai University, Institute for Academic Services. ( 2001). Master Plan for Highland Agriculture Development in Nine Provinces in Upper Northern Region of Thailand.

[17]Chiang Mai University, Institute for Academic Services (2 008). Evaluation Project for Reforestation and Mini- Dam Construction in Upstream Areas..

[18]Mae Fah Luang Foundation under Royal Patronage. (2008). Organization Profile Information

. searched in June 302010 from http://www.maefahluang .org/mission_visi on.php

[19]Rak Thai Foundation. (2 008). Annual Report 2008. .

[20]Rak Thai Foundation. (2 008). Annual Report 2009

[21]Ratana Kittikorn. (2009). Reforestation for Solving Poverty with Rebuilding Human for reforestation(Second Edition).Mae Fah Laung Foundation Publishing.

[22]SirinThon Anthropology Center (Public Organization). (2 004). Knowledge and Politic on Natural Resources..

[23]Highland Research and Development Institute ( Public Organization), Planning and Information Office. ( 2010). Annual Report 2009..

[24] Highland Research and Development Institute (Public Organization), (2 007). Knowledge Management Project and Learning Process for Highland Sustainable Development.

[25]Highland Research and Development Institute ( Public Organization (2 008). Annual Report 2008.

[26]Somporn Sangchai. (2 002). Environment Ideology Politic and Sustainable Development. Bangkok: National Institute for Development Administration, Thailand

[27]Somsanga Charin. (1999). Doi Tung Development Project: Strategy for Sustainable Development. Individual Study for Master Degree in Education, Burapha University . 
[28]Population \& Community Development Association : PDA. (2010). 36 Years in CoDeveloping Thai Society to Sustainability.

[29]Loom Nam Kham Agricultural Cooperatives Limited. (2009). Annual Report 2009, Chiang Rai .Plan International (Thailand). (2 010). Annual Report 2010.

[30]Heifer International (Thailand). ValueBased Holistic Community Development.Principles.

Heifer International (Thailand). (2 010). Annual Report 2009. .

[31]Abhichai Phundhasen and Colleague. (2006).Synthesis on Body of Knowledge of Sufficiency Economy (Second Edition). Bangkok,: Office for Research supporting Fund.

[32]Amara Phongsaphichaya and Colleague (2003). Non-profit Organizations in Thailand Bangkok .: Chulalongkorn University, Social Research Institute.

[33]Uthai Laohavichien. (1985). Development Administration Bangkok: Asia Foundation

[34]Uthai Laohavichien. ( 2003). Public Administration: Disciplines in different dimensions (Eleventh Edition).

[35]Alcock, P. (2010). A strategic unity: Defining the third sector in the UK. Voluntary Sector Review, 1(1), 5-24.

[36]Barnard, C. I. (1976). The functions of the executive. Cambridge, MA: Harvard University Press.

[37]Beierle, T. C., \& Cayford, J. (2002). Democracy in practice: Public participation in environmental decisions. Washington, DC: Resources for the Future.

[38]Bell, R. G. (2001). The conceptual perspective for public participation: Proceedings of the workshop on good governance, public participation and the decision-making process for environmental protection. Bangkok: Saitharn Publication House.

[39]Brown, D. L., \& Rajes, T. (1994). Institutional development for strengthening civil society. Institutional Development, 1(1), 2-17.

[40]Capra, F. (2003). The hidden connections. London: Flaming.

[41]Cumming, T. G., \& Worley, C. G. (2001). Essentials of organization development and change. Cincinnati, OH: South-Western College.
[42]Daft, R. L. (2001). Organization theory and design (7th ed.). Cincinnati, $\mathrm{OH}$ : South-Western College.

[43]De-Shalit, A. (2000). The environment between theory and practice. New York: Oxford University Press.

[44]Drafke, M. W., \& Kossen, S. (2002). The human side of organizations (8th ed.). Upper Saddle River, NJ: Prentice-Hall.

[45]Friedman, H. J. (1970). Administrative roles in local governments. In E. W. Weidner (Ed.), Development administration in Asia (pp. 251-276). Durham, NC: Duke University Press.

[46]Gant, G. F. (1979). Development administration: Concepts, goals, methods. Madison, WI: The University of Wisconsin Press.

[47]Gomez-Mejia, L. R., Balkin, D. B., \& Cardy, R. L. (2005). Management: People, performance, and change. New York: McGraw-Hill.

[48]Goodman, L. J., \& Love, R. N. (1979). Management of development projects. New York: Praeger.

[49]Handy, C. (1993). Understanding organizations. London: Penguin Books.

[50]Hargrove, E. C. (1975). The missing link: The study of the implementation of social policy. Washington, DC: Urban Institute.

[51]Harrison, J. S., \& St. John, C. H. (1998). Foundations in strategic management. Cincinnati, OH: South-Western College.

[52]Jaffee, D. (2001). Organization theory: Tension and change. New York: McGrawHill.

[53]Jones, G. R. (2001). Organizational theory (3rd ed.). Upper Saddle River, NJ: Prentice-Hall.

[54]Korten, D. C. (1987). Third generation NGO strategies: A key to people-centered development. World Development, 15, 145-159.

[55]Laxminarayan, R. (2000). Public participation in environmental decisionmaking: The role of NGOs. Proceedings of RFF-ISEP workshop, Public Participation in Environmental Decision-Making, Bangkok.

[56]Lussier, R. N. (2000). Management fundamentals: Concepts, applications, skill, development. New York: South Western College. 
[57]Matinussen, J. (1997). Society, state and market. New York: Zed Books.

[58]Nutt, P. C., \& Backoff, R. W. (1992).

Strategic management of public and third sector organizations: A handbook for leaders. San Francisco: Jossey-Bass.

[59]Rahman, M. U. (2004). Management of NGOs: A case study in SAARC countries. Unpublished doctoral dissertation, University of Karachi, Karachi, Pakistan.

[60]Riggs, F. W. (1970). The context of development administration. In F. W. Riggs (Ed.), Frontiers of development administration (pp. 74-75). Durham, NC: Duke University Press.

[61]Robbins, S. P. (1990). Organizational theory (3rd ed.). Upper Saddle River, NJ: Prentice-Hall.

[62]Selznick, P. (1953). TVA and the grass roots: A study in the sociology of formal organizations. Berkeley, CA: University of California Press.

[63]Shafritz, J. M., \& Ott, S. J. (2001). Classics of organization theory (5th ed.). New York: Harcourt College.

[64]Simon, H. A., Smithburg, D. W., \& Thompson, V. A. (1968). Public administration. New York: Alfred A. Knopf.

[65]Swerdlow, I. (1963). Economics as part of development administration. In I. Swerdlow (Ed.), Development administration: Concepts and problems (pp. 45-67). New York: Syracuse University Press.

[66]Toft, G. S. (2000). Synoptic (one best way) approaches of strategic management. In J. Rabin, G. J. Miller, \& W. B. Hildreth (Eds.), Handbook of strategic management (2nd ed., pp. 1-30). New York: John Wiley $\&$ Sons.

[67]Tompkins, J. R. (2005). Organization and public management. New York: Thomson $\&$ Wadsworth.

[68]Turner, J. R. (2009). The handbook of project-based management: Leading strategic change in organizations (3rd ed.). New York: McGraw-Hill.

[69]Weidner, E. W. (1962). Development administration: A new focus for research. In F. Heady \& S. L. Stokes (Eds.), Papers in comparative public administration (pp. 98-100). Ann Arbor, MI: The University of Michigan.
[70]Wheelen, T. L., \& Hunger, D. J. (2000). Strategic management and business policy (8th ed.). Reading, MA: Addison-Wesley. 